\title{
Application of molecular methods in forensic analyses of wild animals
}

Irma Ražanskë,

Loreta Griciuvienė,

Asta Aleksandravičienè

Vytautas Magnus University,

K. Donelaičio St. 58,

Kaunas 44248, Lithuania
In European countries, hunting of wildlife is regulated by various directives. However, illegal hunting activities are becoming more common. To deal with wildlife crime cases, it becomes necessary to select the best molecular markers for the analysis of animal sex, species, and relationships identification. This study investigated potential markers within chromosomal and mitochondrial DNA (mtDNA) for animal forensics. By applying markers targeting nuclear DNA and mitochondrial DNA (the cytochrome $b$ gene, hypervariable displacement loop (D-Loop) region, SRY and AMEL genes), the suspected illegal hunting cases were solved by the identification of wild species and sex. Currently, molecular forensic techniques are necessary before conclusions of its validation in forensic investigations.

Keywords: DNA, molecular methods, species identification, sex identification, RFLP

\section{INTRODUCTION}

In European countries, there are a number of directives that regulate hunting management principles and gaming methods for rational resource use. However, the European Union does not have one common law for unified management of hunting across all countries of the EU. The management of wildlife around the world (including Lithuania) is a serious concern in stopping illegal smuggling, hunting, and poaching of wild animals. The Rules of Hunting in the Territory of the Republic of Lithuania establish the list of game species and seasons of hunting of these animals, hunting methods, and their application deadlines, prohibited and permitted gear, a list of hunted game, annual hunting limits in individual units of the hunting area and safe behaviour in hunting and other hunting require-

\footnotetext{
* Corresponding author. Email: irma.razanske@vdu.lt
}

ments (Order of the Minister of the Environment of the Republic of Lithuania on the Approval of the Rules of Hunting in the Territory of the Republic of Lithuania, 27 June 2000, No. 258). Forensic DNA analysis of wildlife animals is the application of DNA forensic methods to proper identification of parts of wildlife animals and their products. To apply the law, it is necessary to properly identify exhibits of each crime to the level of species and sex (Mitra et al., 2018).

Today, molecular markers play an important role in in forensic in estimating an animal's sex, species, and relationships (Bellis et al., 2003). In some cases, it is difficult to perform an examination with very little or poor-quality test material (e.g., blood in sand). In cases of illegal hunting, several types of molecular markers are used, and it is important to mention that none of the molecular markers can be regarded as optimal for all applications. mtDNA sequencing and markers targeting nuclear DNA 
are used for the identification of a biological species from an unknown material (review by Arif et al., 2011). The cytochrome $b$ (cyt $b$ ) gene is one of the most used genetic loci, applied in both taxonomy and forensic science for the purpose of species identification. The gene is 1,140 base pairs long in most vertebrates and shows little intraspecies variation, but sufficient interspecies variation. The gene is too long for typical PCR-based methods and, as many samples are degraded, only a part of the locus is used. DNA sequences at the start of the gene have become the favoured section for phylogenetics and species identification. The DNA sequences from any unknown sample from this part of the cyt $b$ gene can be determined and compared to those on a DNA database to determine the most likely species from which the unknown sample originates (Linacre, 2012).

The purpose of this study is to investigate potential markers within chromosomal and mitochondrial DNA (mtDNA) for wildlife forensics.

\section{MATERIALS AND METHODS}

\section{DNA extraction}

To prove illegal hunting of animals, a wide variety of material has been collected for this study: pieces of tissue, blood, blood stains from various surfaces, soil with blood residues, bristles, bones, and the like. Depending on the type of material collected for research, different methods and kits such as Genomic DNA Purification Kit (Thermo Scientific ${ }^{\mathrm{Tx}}$ ), GeneJET Whole Blood Genomic DNA Purification Mini Kit (Thermo Scientific $^{\text {TM }}$ ), QIAamp DNA Mini Kit (Qiagen), PrepFiler ${ }^{\mathrm{TM}}$ Forensic DNA Extraction Kit (Applied Biosystems ${ }^{\mathrm{TM}}$ ) for DNA extraction were used. The quantity of DNA was measured, the quality was assessed, and DNA was stored at $-20^{\circ} \mathrm{C}$ until PCR analysis.

\section{Species identification}

To identify a mammal's species from different samples, PCR amplification was performed using primers L14735 (5'-AAAAACCACCGTTGTTATTCAACTA-3') and H15149 (5'-AAACT-
GCAGCCCCTCAGAATGATATTTGTCCTCA-3') of a partial cytochrome $b$ gene sequence (308 bp) (Kocher et al., 1989; Spielmann et al., 2018).

In order to identify an animal species and using a short part of the target gene sequence, it may be difficult to distinguish related species or subspecies. For example, species-specific primers Pig F (5'-AAACTGCAGCCCCTCAGAATGATATTTGTCCTCA-3') and Pig R (5'-ACCATTGACTGAATAGCACCT-3')(Montiel-Sosa et al., 2000) designed for pork D-loop mtDNA were developed. The amplified band of $531 \mathrm{bp}$ indicates that there is pork in the sample and this band is absent in PCR-amplified products from bovine, ovine, chicken, and human samples. To distinguish wild boar meat from pork, the restriction fragment length polymorphism (RFLP) analysis was done. Pork and wild boar amplified DNA can be easily distinguished by digestion with the BseDI (BsaJI) (Thermo Scientific $\left.^{\mathrm{TM}}\right)$ restriction enzyme for $8 \mathrm{~h}$ at $55^{\circ} \mathrm{C}$.

\section{Sex determination}

The first sex determination test was developed by Pomp et al. (1995). The primer pair SRYB F (5'-TGAACGCTTTCATTGTGTGGTC-3') and SRYB R (5'-GCCAGTAGTCTCTGT GCCTCCT-3') was applied to investigate samples of unknown sex. An amplified product of $163 \mathrm{bp}$ is only expected in males that carry the Y chromosome.

For amplifying the amelogenin gene of the sheep and the red deer, the set of primers SE47 (5'-CAGCCAAACCTCCCTCTGC-3') and SE48 (5'-CCCGCTTGGTCTTGTCTGTTGC-3') was used earlier (Ennis, Gallagher, 1994; Pfeifer, Brenig, 2005). In this study, individuals of the roe deer, the red deer, the moose, the wild boar, and the pig were analysed. One band 244 bp was produced by samples from females, samples from males amplified three bands (one non-specific band was observed; specific bands should be 244 and $190 \mathrm{bp}$ ).

Detailed PCR protocols used in this study of different targets are presented in the Table.

PCR amplification products were separated by gel electrophoresis in $0.5 \times$ TAE buffer 
Table. Detailed PCR protocols

\begin{tabular}{|c|c|c|}
\hline Target & Components of PCR & PCR amplification steps \\
\hline \multirow[t]{5}{*}{ cyt $b$} & 1X DreamTaq Green PCR MM & $95^{\circ} \mathrm{C}-15 \mathrm{~min}$ \\
\hline & $0.5 \mu \mathrm{M}$ Forward primer & $94^{\circ} \mathrm{C}-40 \mathrm{~s}$ \\
\hline & $0.5 \mu \mathrm{M}$ Reverse primer & $35 \mathrm{X} 50^{\circ} \mathrm{C}-1 \min 20 \mathrm{~s}$ \\
\hline & $\sim 100$ ng DNA & $72^{\circ} \mathrm{C}-1 \min 20 \mathrm{~s}$ \\
\hline & & $72^{\circ} \mathrm{C}-10 \mathrm{~min}$ \\
\hline \multirow[t]{5}{*}{ D-loop } & $1 \mathrm{X} \mathrm{MyTaq}^{\mathrm{TM}}$ Reaction Buffer & $92^{\circ} \mathrm{C}-3 \mathrm{~min}$ \\
\hline & 2U MyTaq ${ }^{\mathrm{Tm}}$ DNA Polymerase & $92^{\circ} \mathrm{C}-20 \mathrm{~s}$ \\
\hline & $2.5 \mathrm{mM}$ Forward primer & $30 \mathrm{X} 58^{\circ} \mathrm{C}-20 \mathrm{~s}$ \\
\hline & $2.5 \mathrm{mM}$ Reverse primer & $72^{\circ} \mathrm{C}-30 \mathrm{~s}$ \\
\hline & $\sim 100$ ng DNA & $72^{\circ} \mathrm{C}-3 \min$ \\
\hline \multirow[t]{5}{*}{ SRY } & 1X DreamTaq Green PCR MM & $95^{\circ} \mathrm{C}-5 \mathrm{~min}$ \\
\hline & $1 \mu \mathrm{M}$ Forward primer & $95^{\circ} \mathrm{C}-30 \mathrm{~s}$ \\
\hline & $1 \mu \mathrm{M}$ Reverse primer & $35 \mathrm{X} 56^{\circ} \mathrm{C}-30 \mathrm{~s}$ \\
\hline & $\sim 100$ ng DNA & $72^{\circ} \mathrm{C}-30 \mathrm{~s}$ \\
\hline & & $72^{\circ} \mathrm{C}-5 \mathrm{~min}$ \\
\hline \multirow[t]{5}{*}{ AMEL } & 1X DreamTaq Green PCR MM & $95^{\circ} \mathrm{C}-10 \mathrm{~min}$ \\
\hline & $1 \mu \mathrm{M}$ Forward primer & $94^{\circ} \mathrm{C}-50 \mathrm{~s}$ \\
\hline & $1 \mu \mathrm{M}$ Reverse primer & $35 \mathrm{X} 56^{\circ} \mathrm{C}-50 \mathrm{~s}$ \\
\hline & $\sim 100$ ng DNA & $72^{\circ} \mathrm{C}-1 \mathrm{~min}$ \\
\hline & & $72^{\circ} \mathrm{C}-2 \min$ \\
\hline
\end{tabular}

(Thermo Scientific ${ }^{\mathrm{TM}}$ ) using $1.5-2 \%$ agarose at $100 \mathrm{~V}$ for $60 \mathrm{~min}$, stained with ethidium bromide and visualised under UV light. The amplicons of species identification reaction $(c y t b)$ obtained from amplification were purified using GeneJET Gel Extraction Kit (Thermo Scientific $^{\mathrm{TM}}$ ) following the manufacturer's instructions. Purified PCR products were sent to a sequencing service (Macrogen, Amsterdam, Netherlands). The obtained sequences of different species were compared with sequences available from the GenBank database (www. ncbi.nlm.nih.gov) using the BLASTn tool of the National Center for Biotechnology Information. The identification and phylogenetic analysis of a mammal's species were conducted using MEGA X software (Kumar et al., 2018).

\section{RESULTS AND DISCUSSION}

\section{mtDNA}

Mitochondrial DNA (mtDNA) is widely used in forensic analyses because the cell has a high number of mtDNA copies, which facilitate analysis from samples with highly degraded DNA, poor-quality test material, or trace amounts of DNA (Ballard, 2016). mtDNA is a relatively small, easy to isolate DNA molecule, and due to the presence of conserved sites such as the 12S, 16S, and cytochrome $b$ (cyt $b$ ) gene, these fragments are widely used for species identification (Singh et al., 2017). The mtDNA control region spans over $1122 \mathrm{bp}$, evolves faster than the rest of the mitochondrial genome, and the three hypervariable regions of the control region, HVI, HVII, and HVIII, are also used for forensic investigation (Nakamura et al., 2008). In this study, fragments of the cyt $b$ gene from potentially unknown mammals were amplified and sequenced. Comparison of the obtained data with the sequences uploaded in the NCBI Nucleotide database revealed that the tested animals were a red deer, a roe deer, a moose, and a wild boar. Compared sequence similarity ranged from 99 to $100 \%$. Parson et al. (2000) conducted a study using cyt $b$ gene. All cyt $b$ gene sequences of the tested mammalian 
species and the amphibians were found in DNA databases. The high similarity between the laboratory results and the database entry (99 and 100\%) were also observed. These authors concluded that single nucleotide substitutions between the query and the subject sequence could be attributed to individual variation (Parson et al., 2000).

\section{Restriction Fragment Length Polymorphism (RFLP)}

The amplified product of mtDNA D-loop (531 bp) of the wild boar and the pig using primer pair Pig F and Pig R was observed in all tested samples. Based on these obtained results alone, it was not possible to identify a specific species, so RFLP analysis could be used to avoid sequencing. In this study, BsaJI (BseDI) restriction enzyme (Fig. 1) was used for amplified $\mathrm{mtDNA}$ digestion.

Digestion of the $531 \mathrm{bp}$ amplified DNA fragment are shown in Fig. 2 and produced the ap- pearance of one intense band of approx. $420 \mathrm{bp}$ and one weak band of approx. $110 \mathrm{bp}$ in pork meat and two intense bands of approx. 230, $210 \mathrm{bp}$ and one weak band of approx. $110 \mathrm{bp}$ in wild boar. In future work, capillary electrophoresis rather than the agarose gel should be used due to its better resolution.

A comparison of our results with MontielSosa et al. (2000) showed that the PCR amplification products also produced a single band with the molecular size of $531 \mathrm{bp}$. BsaJ endonuclease produced a single band with the molecular size of $470 \mathrm{bp}$ in pork meat and undigested single band of $531 \mathrm{bp}$ in the wild boar. However, the enzyme also produced smallest bands in the study by Montiel-Sosa et al. (2000), but the authors were not able to detect them and these results cannot be compared with our own results. More mutation regions in animals from different countries and continents could be identified if more restriction endonucleases are tested.

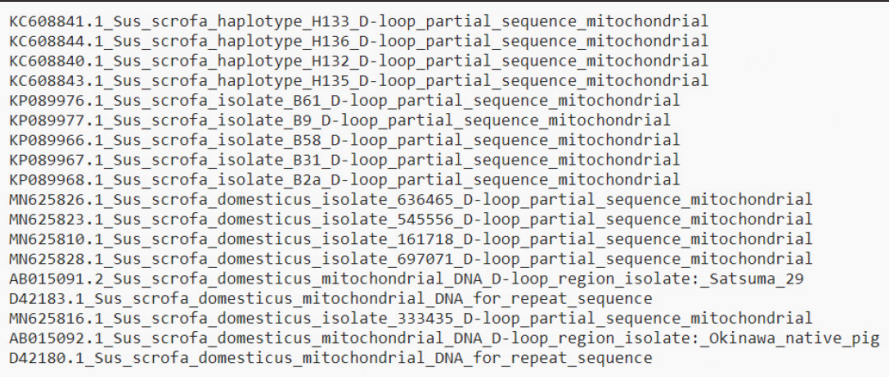

Fig. 1. Comparison of fragments of pig (Sus scrofa domesticus) and wild boar (Sus scrofa) mtDNA D-loop sequences from GenBank database (https://www.ncbi.nlm.nih.gov/nuccore/). The recognition sites of BsaJI (BseDI) restriction endonuclease in wild boar sequences are marked in yellow

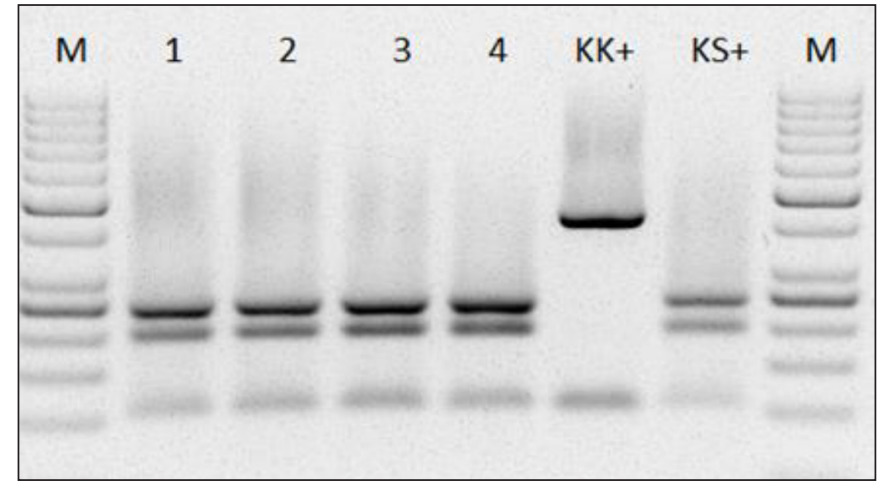

Fig. 2. Electrophoresis analysis in $2 \%$ agarose gels of the products obtained with BseDI digestion of the amplified wild boar and pig mtDNA. Lines 1-4 represent samples from wild boar, line $\mathrm{KK}+$ is a sample from pig, and line $\mathrm{KS}+$ is a sample from wild boar. Lines $\mathrm{M}$ are $50 \mathrm{bp}$ ladder DNA marker 


\section{Sex determination}

Sex determination using molecular markers in domestic and wild animals are important in different fields: breeding (Sathasivam et al., 1995), meat production and processing (Zeleny et al., 2002), population genetics (Taberlet et al., 1993), forensics (Gupta et al., 2006), and others. Using several species of mammals, sex determination methods were developed by amplification of specific sequences of Y-chromosome or amplifying homologous fragments from both sex chromosomes (Fontanesi et al., 2008). The first molecular studies of sex determination were performed using the SRY gene in pigs (Pomp et al., 1995; Sathasivam et al., 1995). However, the disadvantage of this method is that the amplified product is only expected in males. Using this test alone can be problematic; it is not possible to distinguish the failure of PCR amplification from the correct identification of the samples as females (Fontanesi et al., 2008). For example, in this study, four animals (wild boar) for which the sex was not available and two animals for which the sex was available were analysed and compared (Fig. 3). In this study, these molecular markers for sex determination were also verified and validated for the roe deer, the red deer, and the moose (data not shown).

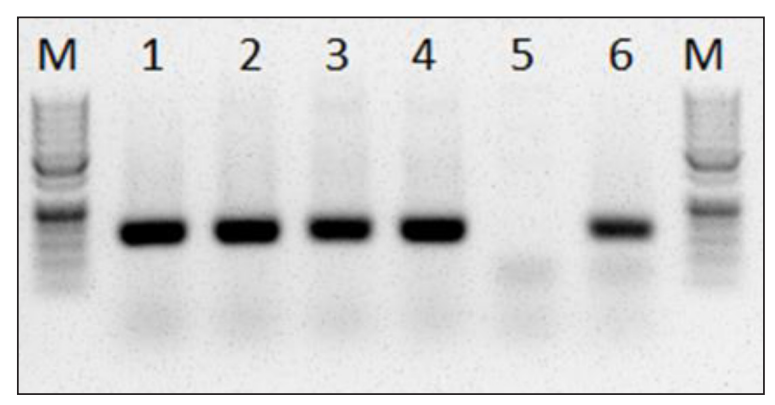

Fig. 3. Electrophoresis analysis in 1.5\% agarose gel of sex determination based on the protocol described by Pomp et al. (1995). SRY gene PCR fragments specific to males $(1,2,3,4,6)(163 \mathrm{bp})$ are shown. Line 1-4 samples come from wild boar of unknown sex, line 5 is a sample from a female wild boar, line 6 is a sample from a male wild boar. Lines $\mathrm{M}$ are 50 bp ladder DNA marker
Another gene used in sex determination cases in different mammalian species is amelogenin. $\mathrm{X}$ and $\mathrm{Y}$ chromosome-specific sequence differences of the amelogenin genes (AMELX and AMELY) were described (Fontanesi et al., 2008). The use of this gene in molecular analysis made the sex determination much less complicated, since only one pair of primers is required to amplify the different size fragments of the AMEL genes (Pfeiffer and Brenig, 2005). For example, four animals (roe deer individuals), for which the sex was not available, and five animals (roe deer and red deer individuals), for which the sex was available, were analysed and compared (Fig. 4). A single band for females and three bands (an additional nonspecific band also was observed) for males were detected when analysing samples of different animals. Based on different banding patterns, there was no problem determining the sex of each individual.

The same results were observed in Pfeiffer and Brenig's (2005) study with sheep and red deer: a single band for females and two bands with one additional non-specific band for males were detected.

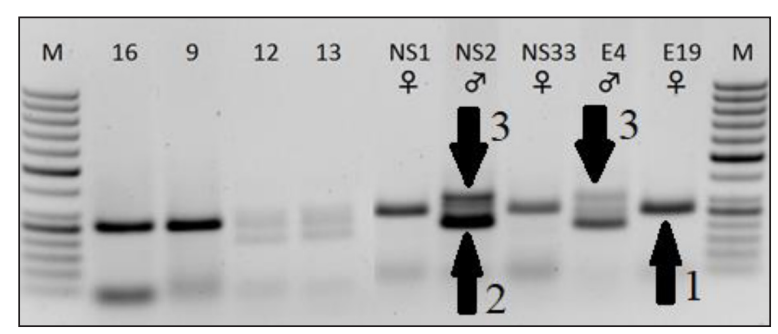

Fig. 4. Electrophoresis analysis in $1.5 \%$ agarose gel of sex determination based on the protocol described by Pfeiffer and Brenig, 2005. Arrow 1 indicates the AMELX band, arrow 2 indicates the AMELY band, and arrow 3 indicates non-specific bands in male roe deer and red deer. Lines 16, 9, 12, 13 are samples from red deer of unknown sex, lines NS1 and NS33 are samples from a female roe deer, line NS2 is a sample from a male roe deer, line E4 is a sample from a male red deer, and line E19 is a sample from a female red deer. Lines $M$ are $50 \mathrm{bp}$ ladder DNA marker 


\section{CONCLUSIONS}

The molecular markers used in this study are suitable for species and sex identification. Even very small amounts of different testing materials can be used to identify specific animals (species and sex) hunted in illegal hunting.

Received 20 October 2021 Accepted 16 November 2021

\section{References}

1. Arif IA, Khan HA, Bahkali AH, Al Homaidan AA, Al Farhan AH, Al Sadoon M, Shobrak M. DNA marker technology for wildlife conservation. Saudi J Biol Sci. 2011; 18: 219-25.

2. Ballard D. Analysis of mitochondrial control region using Sanger sequencing. Methods Mol Biol. 2016; 1420: 143-55.

3. Bellis C, Ashton KJ, Freney L, Blair B, Griffiths LR. A molecular genetic approach for forensic animal species identification. Forensic Sci Int. 2003; 134: 99-108.

4. Ennis S, Gallagher TF. A PCR-based sec-determination assay in cattle based on the bovine amelogenin locus. Anim Genet. 1994; 25: 425-7.

5. Fontanesi L, Scotti E, Russo V. Differences of the porcine amelogenin $\mathrm{X}$ and $\mathrm{Y}$ chromosome genes (AMELX and AMELY) and their application for sex determination in pigs. Mol Reprod Dev. 2008; 75: 1662-8.

6. Gupta SK, Thangaraj K, Singh L. A simple and inexpensive molecular method for sexing and identification of the forensic samples of elephant origin. J Forensic Sci. 2006; 51: 805-7.

7. Kocher TD, Thomas WK, Meyer A, Edwards SV, Pääbo S, Villablanca FX, Wilson AC. Dynamics of mitochondrial DNA evolution in animals: amplification and sequencing with conserved primers. Proc Natl Acad Sci USA. 1989; 86: 6196-200.
8. Kumar S, Stecher G, Li M, Knyaz C, Tamura K. MEGA X: Molecular Evolutionary Genetics Analysis across Computing Platforms. Mol Biol Evol. 2018; 35: 1547-9.

9. Linacre A. Capillary electrophoresis of $\mathrm{mtD}$ NA cytochrome $b$ gene sequences for animal species identification. Methods Mol Biol. 2012; 830: 321-9.

10. Minister of the Environment of the Republic of Lithuania order on approval of rules for hunting in the territory of the Republic of Lithuania 2000 June 27; No. 258 Vilnius.

11. Mitra I, Roy S, Haque I. Application of molecular markers in wildlife DNA forensic investigations. J Forensic Sci Med. 2018; 4: 156-60.

12. Montiel-Sosa JF, Ruiz-Pesini E, Montoya J, Roncalés P, López-Pérez MJ, Pérez-Martos A. Direct and highly species-specific detection of pork meat and fat in meat products by PCR amplification of mitochondrial DNA. J Agric Food Chem. 2000; 48: 2829-32.

13. Nakamura S, Murakami C, Irie W, Kobayashi M, Maeda K, Sasaki C, Nakamaru N, Furukawa M, Kurihara K. Analysis of mtDNA control region using mitoSEQr ${ }^{\mathrm{TM}}$ resequencing system and its forensic application. Forensic Sci Int Genet Suppl Ser. 2008; 1: 292-4.

14. Parson W, Pegoraro K, Niederstätter $H$, Föger M, Steinlechner M. Species identification by means of the cytochrome $\mathrm{b}$ gene. Int J Legal Med. 2000; 114: 23-8.

15. Pfeiffer I, Brenig B. X- and Y-chromosome specific variants of the amelogenin gene allow sex determination in sheep (Ovis aries) and European red deer (Cervus elaphus). BMC Genet. 2005; 6: 16.

16. Pomp D, Good BA, Geisert RD, Corbin CJ, Conley AJ. Sex identification in mammals with polymerase chain reaction and its use to examine sex effects on diameter of day-10 or -11 pig embryos. J Anim Sci. 1995; 73: 1408-15.

17. Sathasivam K, Kageyama S, Chikuni K, Notarianni E. Sex determination in the domestic 
pig by DNA amplification using HMGbox sequence. Anim Reprod Sci. 1995; 38: 321-6.

18. Singh A, Kumar A, Kumar RS, Bhatt D, Gupta SK. Amplification of mtDNA control region in opportunistically collected bird samples belonging to nine families of the order Passeriformes. Mitochondrial DNA B Resour. 2017; 2(1): 99-100.

19. Spielmann M, Lupiáñez DG, Mundlos S. Structural variation in the $3 \mathrm{D}$ genome. Nat Rev Genet. 2018; 19: 453-67.

20. Taberlet P, Mattock H, Dubois-Paganon C, Bouvet J. Sexing free-ranging brown bears $U r$ sus arctos using hairs found in the field. Mol Ecol. 1993; 2: 399-403.

21. Zeleny R, Bernreuther A, Schimmel H, Pauwels J. Evaluation of PCR-based beef sexing methods. J Agri Food Chem. 2002; 50: 4169175.

\section{Irma Ražanskė, Loreta Griciuvienè,} Asta Aleksandravičienè

\section{LAUKINIŲ GYVŪNŲ KRIMINALISTINĖ ANALIZĖ MOLEKULINIAIS TYRIMŲ METODAIS}

\section{Santrauka}

Europos šalyse galioja įvairios laukinių gyvūnų medžioklès direktyvos. Visame pasaulyje (ir Lietuvoje) laukinių gyvūnų populiacijų valdymas kelia rimtą susirūpinimą - siekiama sustabdyti nelegalią laukinių gyvūnų kontrabandą ir medžioklę. Tiriant nusikaltimų laukinei gamtai bylas, būtina parinkti geriausius molekulinius žymenis gyvūnų lyties, rūšies ir giminystès identifikavimo analizei. Šiame tyrime buvo išanalizuoti chromosominiai ir mitochondriju DNR (mtDNR) žymenys, kurie galètų būti taikomi laukinių gyvūnų teismo ekspertizeje. Naudojant šiuos žymenis (mtDNR citochromo b geną ir variabilų D kilpos (D-Loop) regioną; SRY ir AMEL genus), buvo nagrinèjami ịtariamos nelegalios medžioklès atvejai, identifikuotos laukinių gyvūnų rūšys ir nustatytos lytys. Molekuliniai DNR metodai yra būtini ir naudingi atliekant teisminę ekspertizę.

Raktažodžiai: DNR, molekuliniai metodai, rūšių identifikavimas, lyties identifikavimas, RFLP 